\title{
Overweight and Obesity among Preschool Children Attending A Rural Family Health Unit in Menoufia Governorate
}

Nora A. Khalil (MD) ${ }^{1}$, Dalia M. Ellahony (MD) ${ }^{2}$, Alaa A. Megahed (M.B.B.Ch) ${ }^{3^{*}}$

${ }^{1}$ Family Medicine Department, Faculty of Medicine, Menoufia University, Menoufia, Egypt,

${ }^{2}$ Pediatric Department, Faculty of Medicine, Menoufia University, Menoufia, Egypt , ${ }^{3}$ Ministry of Health, Tala, Menoufia, Egypt

\begin{abstract}
:
Background: Obesity in preschool children is a growing problem as it is a predictor of adulthood obesity, morbidity and mortality. Objectives: To assess prevalence of overweight and obesity and identify risk factors associated with them among preschool children. Methods: A cross sectional study was conducted on 248 preschool children of both sexes, aged between 2-5 years in rural area in Menoufia Governorate. Sociodemographic data of the studied children and their eating practices were collected. Weight and height were measured and body mass index (BMI) was calculated. Egyptian practice guidelines were used for cut-off values of BMI-for-age, and percentiles were used to determine the prevalence of overweight and obesity. Results: The overall prevalence of combined overweight and obesity was $21 \% 15$ (\% for overweight and $6 \%$ for obesity). Higher prevalence was found among participants aged from 3-4 years old $(46.7 \%)$ and among males (80\%). Mothers' education, frequency of consuming junk and fried food was closely associated with overweight and obesity $(\mathrm{p}<0.05)$. Also, BMI is significantly affected by mothers' feeding behavior such as allowing the child to eat alone, offering him sweets regularly, using sweets as a reward, mothers' concern about overweight, and keeping food out of reach. Conclusion: Prevalence of preschool obesity increases with multiple risk factors, such as mother's education, frequency of consuming junk and fried food. BMI was affected by mothers' feeding behavior. So, the first five years of life are the best period for primary prevention of obesity.
\end{abstract}

Key words: Prevalence, Risk Factors, Eating Habits.

\section{Introduction:}

Overweight and obesity are defined as excessive accumulation of fat that may impair health. ${ }^{(1)}$ Globally, the prevalence of overweight and obesity among preschool children increased from $4.2 \%$ in 1990 to $6.7 \%$ in $2010 .^{(2)}$ World Health Organization (WHO) reported that, about 340 million children and teenagers aged 5-19 years old were diagnosed as overweight/obese. ${ }^{(3)}$ Many factors can be associated with overweight and obesity in preschool children. From this, factors which are on the maternal side were socioeconomic status, level of education, marital status and, maternal smoking during pregnancy. Child gender, birth weight and the child's birth rank, BMI of parents, area of residence and some nutritional habits have also been found to be factors of childhood overweight and obesity. ${ }^{(4)}$ Researchers believe that the increased prevalence of obesity is the result of changes in the lifestyle of societies, such as the inactivity, collapse of energy balance, increased consumption of fast food and

*Corresponding author: E-mail: dralaamegahed1288@gmail.com 
animal proteins and increased use of technology. ${ }^{(5)}$

Childhood overweight and obesity are considered a global public health problem since it increases the risk of developing diabetes, cancer, cardiovascular diseases and many other physical or social problems and complications in adulthood. ${ }^{(6)}$ It also causes undesirable psychological consequences, such as anxiety, depression, sleep disorders and low self-esteem, which could affect the educational and social relationships of children. ${ }^{(7)}$

Childhood obesity may persist for life if not managed properly; it can lead to adulthood obesity and a variety of metabolic and cardiovascular consequences later in life. Therefore, pediatric obesity is regarded as one of the priority health issues, and the treatment of childhood obesity and its complications may be one of the most effective strategies to reducing morbidities and mortalities and to saving hospital costs later in life. ${ }^{(8)}$

The study was conducted to assess the prevalence of overweight and obesity and to identify the main risk factors associated with them among preschool children attending the selected Family Health Unit (FHU) in a village in Menoufia GovernorateEgypt in order to aid in providing more suitable care for them in the future.

\section{Methods:}

The study was a cross sectional study. It was conducted in the context of time frame of fourteen months from March 2018 till May 2019.

Study setting was selected through multistage random sampling technique. Tala district was selected to represent Menoufia governorate in Egypt. Then (Tokh Dalaka) village was randomly selected from 26 villages in Tala district. Its FHU represented the site for data collection.

Ethical Approval: The study was approved by the Ethical Committee of the Faculty of Medicine, Menoufia University. Informed consent was obtained from all participants after simple and clear explanation of the research objectives and methodology. The calculated sample size was 248 . It was determined using on line Raosaft sample size calculator for a definite population.

It was calculated based on the prevalence of overweight and obesity in preschool children in Egypt, which is $(22 \%)^{(13)}$ and the total number of target population was (4031), those are children aged from 2-5 years in Tokh 
Dalaka village obtained from Information Center, local authority center in Tala with power of $80 \%$, confidence interval of $95 \%$ and 0.05 as the absolute sampling error that can be tolerated. All participants were interviewed using a validated questionnaire.

The questionnaire included: personal data for assessment of sociodemographic characteristics, questions assessing past history of the child, and different factors possibly related to obesity such as dietary habits of the child (number of meals, number and kind of snacks per day, drinking milk, eating milk products, vegetables, fruits), and mothers' attitude toward the child's eating habits such as eating alone, offer sweets as reward.

Regular sweet intake, eat without being hungry, concern about overweight, and keeping food out of reach.

Statistical Analysis: Data were analyzed using Statistical package of Social Science (SPSS) version 20 (using Integrated Best Management (IBM) personal computer). Quantitative data (age) were expressed as mean and

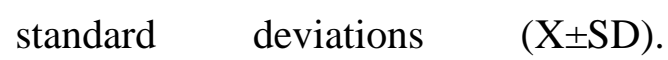
Qualitative data were expressed as number and percentage and analyzed applying Chi-square test.

\section{Results:}

A total of 248 healthy children aged 25 years participated in this study (129 boys and 119 girls). Based on the BMIfor-age percentiles, it was found that prevalence of combined overweight and obesity were $21 \%$, (15\% for overweight and $6 \%$ for obesity) (Figure 1). In the current study, there was a significant difference in prevalence of overweight and obesity based on children's age. Children aged 3-4 years reported the highest prevalence of overweight $(22.7 \%)$, and obesity (10.6\%), while the lowest prevalence of overweight was in children aged 2-3years at $3.4 \%$ and the lowest prevalence of obesity was in children aged 4-5years at $1.7 \%$, (Figure 2).

This study showed that there was gender-specific prevalence of overweight and obesity where $80 \%$ of boys were obese versus $20 \%$ of girls. However, overweight was significantly more frequent in girls (73\%) versus $27 \%$ in boys. Overweight and obese children were significantly more prevalent among housewife-mothers $(60 \%$ and $80 \%$ respectively) in comparison to working mothers, and among mothers with high educational 
level (54\%, $86.7 \%$ respectively)

(Table1)

The current study indicates that there is a significant relationship between BMI and frequency of junk food consumption, as $75.7 \%$ of overweight children were eating junk food daily, and $67.6 \%$ of overweight children were eating fried food 1-2 times/per week. Also, drinking milk and eating dairy products on daily basis were significantly higher among obese children $(93.3 \%, 80 \%$ respectively). However, no significant correlation was found between BMI and (frequency of eating vegetables, fruits and animal proteins). (Table 2).

Regarding dietary habits and life style, this study showed that $54 \%$ of children were overweight Also there was no significant relation between body mass index (BMI) and the number or type of snacks per day. About $93 \%$ of obese children had no outdoor activities, and $100 \%$ of them did not practice sport regularly, which had a statistically significant correlation with the degree of obesity (Table 3)

Regarding the maternal feeding behavior, it was observed that $81 \%$ of overweight, and $93.3 \%$ of obese children were allowed by their mothers to eat alone $(p$-value $=0.0030$. Also
$86.5 \%$ of overweight children were eating sweet regularly. About $81 \%$ of overweight and $93.3 \%$ of obese children had mothers who were concerned about overweight. About $84 \%$ of overweight and $66.7 \%$ of obese children had mothers who did not keep food out of reach, which was statistically significant, however no significant relation between BMI and sweets intake as a reward or forcing child to eat without being hungry (Table 4).

\section{Discussion:}

In the current study the overall prevalence of combined overweight and obesity was $21 \%$ (15\% for overweight and $6 \%$ for obese). These findings were higher than the Demographic and Health Surveys (DHS) results in 2014 conducted by El-Zanaty et al ${ }^{(9)}$ who reported that $17.3 \%$ was prevalence of combined overweight and obesity among children from 0-59 months in the Urban Lower Egypt sample. Also, Dekkaki et al (10) study which was conducted in Morocco found that the prevalence of overweight and obesity was $8.7 \%$.

Overweight affected $5.1 \%$ and obesity affected $3.6 \%$. However, these results were lower than the results of Rizk et al (11) study which was 
conducted in Qatar and showed a high prevalence of pediatric overweight and obesity, in Qatari children $(31.71 \%$ in boys and $33.78 . \%$ in girls). But these results were consistent with research in Vietnam by Do et al ${ }^{(12)}$ where the combined prevalence of overweight and obesity was $21.1 \%$. In the present study, age was associated with childhood overweight/obesity. The lowest prevalence of overweight and obesity was in children aged 2-3 years, while the highest prevalence of obesity was in children aged 3-4years then it decreased at age 4-5years.

This result was similar to data from DHS in Egypt, which showed a similar trend where children from 4-5 years exhibit the least prevalence for overweight WHO. ${ }^{(13)}$ Possible explanation is that in the first two years of life, the child is dependent on his mother for feeding with less activity. Probable improper feeding at this stage may contribute to excess weight. Conversely, the toddler is more active with less temptation towards food. The current study reported that there was statistically significant association between obesity and mother's education as $86.7 \%$ of obese children had highly educated mothers. This result was in agreement with the findings of $\mathrm{Al}$ Alawi et al ${ }^{(14)}$ study that conducted Kingdom of Bahrain reported that higher parental education status is associated with an increase in the prevalence of overweight and obesity among their children. The risk of childhood overweight and obesity significantly increases if the parents are university graduates and this also was supported by a study in India conducted by Pauline et al. ${ }^{(15)}$

The current study revealed that there was no significant relationship between body mass index and socioeconomic characters. This result agreed with a study conducted by Saleh et al ${ }^{(16)}$ in Egypt, which reported that income did not show any significant relation to overweight / obesity. However, Tzioumis et al (17) study founded that Children who were from high income families were more likely to be overweight/obese as compared to low income families' children. This result contrasted the results of a study done by Moraeus et al ${ }^{(18)}$ in Sweden that reported that high socioeconomic status was associated with lower risk of overweight. Regarding dietary habits there was a significant relationship between BMI and frequency of junk food and fried food. This is in consistency with findings of researches 
done by Freedman et al ${ }^{(19)}$ in United States, which indicated that infants with the dietary pattern characterized by foods high in energy density (French fries and sweet desserts) had a higher prevalence of overweight at the age of six. On the contrary, the study of Olsho et al ${ }^{(20)}$ among children and adolescents aged 2 to 18 who consumed potatoes demonstrated that potatoes, including French Fries, provided a significant source of at least 10 essential vitamins and minerals in the diet, including dietary fiber.

Also, the current study revealed that there was a significant relation between BMI and offering sweets regularly. Which is similar to the results of Wolde et al ${ }^{(21)}$ study in south Ethiopia which revealed that those who ate sweet foods showed significant association with childhood overweight/obesity. As regard maternal feeding behavior, there was a significant relationship between BMI and maternal feeding behavior as regard (allowing the child to eat alone, offering him sweets regularly, offering sweets as a reward, maternal concern about overweight and keeping food out of reach). These findings were inconsistency with findings from a study conducted by Rodgers et al (22) which supported the importance of maternal feeding practices in relation to child weight gain and the development of obesogenic eating behaviors in young children.

Conclusion: The overall prevalence of combined overweight and obesity among the studied group was $21 \%$ (15\% for obese $\& 6 \%$ for obese). Prevalence of preschool obesity increases with some risk factors such as mother's education, frequency of junk food and fried food, Also, there was a significant relationship between body mass index and maternal feeding behavior such as offering sweets as a reward and keeping food out of reach. So, the first under five years of life may well be the best period for intervention regarding primary obesity prevention.

Study limitation: The questionnaire used was long and took about 30 minutes to complete. This obstacle was overcome by the interview, because data were collected after the end of the working day in a convenient appointment for the mothers of the studied children.

The study was self-funded.

Acknowledgment: The authors of the paper would like to thank all participants of the study, the field workers, the Municipality of tala 
district, and the higher education ethical committee of Menoufia University.

Funding: No fund

Conflicts of interest: No conflict of interest to be declared

\section{References}

1. World Health Organization (WHO). Obesity and overweight 2016. Available at https://www.who.int/news-room/factsheets/detail/obesity-and-overweight (Accessed Feb 16th, 2018).

2. De Onis M, Blössner M, Borghi E. Global prevalence and trends of overweight and obesity among preschool children. The American journal of clinical nutrition. 2010 Sep 22;92(5):1257-64.

3. Nahhas MA, Asamoah F, Mullen S, et al. Epidemiology of overweight and obesity in early childhood in the Gulf Cooperation Council countries: a systematic review and meta-analysis protocol. BMJ open. 2018 Jun 1;8(6): 019363.

4. Toselli S, Zaccagni L, Celenza F, et al. Risk factors of overweight and obesity among preschool children with different ethnic background. Endocrine. 2015 Aug 1;49(3):71725.

5. Rahmani A, Sayehmiri K, Asadollahi K, et al. Investigation of the prevalence of obesity in Iran: a systematic review and metaanalysis study. Acta Medica Iranica. 2015 Oct 27:596-607.

6. Gies I, AlSaleem B, Olang B, et al. Early childhood obesity: a survey of knowledge and practices of physicians from the Middle East and North Africa. BMC pediatrics. 2017 Dec;17(1):115.

7. Hudda MT, Nightingale CM, Donin AS, et al. Patterns of childhood body mass index (BMI), overweight and obesity in South Asian and black participants in the English National child measurement programme: effect of applying BMI adjustments standardizing for ethnic differences in BMI-body fatness associations. International Journal of Obesity. 2018 Apr;42(4):662.

8. Yi DY, Kim SC, Lee JH, et al. Clinical practice guideline for the diagnosis and treatment of pediatric obesity: recommendations from the Committee on Pediatric Obesity of the Korean Society of Pediatric Gastroenterology Hepatology and Nutrition. Pediatric gastroenterology, hepatology \& nutrition. 2019 Jan 1;22(1):1-27.

9. El-Zanaty F, ICF International. Egypt Health Issues Survey 2015. 
Cairo, Egypt and Rockville, Maryland, USA: Ministry of Health and Population and ICF International; 2015, 5(4): 74.

10. Dekkaki IC, Mouane N, Ettair S, et al. Prevalence of obesity and overweight in children: a study in government primary schools in Rabat, Morocco. Archives of medical research. 2011 Nov 1;42(8):703-8.

11. Rizk NM, Yousef M. Association of lipid profile and waist circumference as cardiovascular risk factors for overweight and obesity among school children in Qatar. Diabetes, metabolic syndrome and obesity: targets and therapy. 2012;5: 425.

12. Do LM, Tran TK, Eriksson B, et al. Preschool overweight and obesity in urban and rural Vietnam: differences in prevalence and associated factors. Global health action. 2015 Dec 1;8(1):28615.

13. World Health Organization (WHO). WHO Global Database on Child Growth and Malnutrition. September 2010. http://www.who.int/nutgrowthd b/database (Accessed May 15th, 2013).
14. Al Alawi S, Abdulatif F, Al Dhubaib D, et al. Prevalence of overweight and obesity across preschool children from four cities of the Kingdom of Bahrain. International Journal of Medical Science and Public Health. 2013 Jul 1;2(2):507-10.

15. Pauline M, Selvam S, Swaminathan $\mathrm{S}$, et al. Body weight perception is associated with socio-economic status and current body weight in selected urban and rural South Indian school-going children. Public health nutrition. 2012 Dec;15(12):2348-56.

16. Saleh M, Anwar W, Habil I, et al. Prevalence of overweight and obesity among a sample of underfive rural children in Lower Egypt. The Egyptian Journal of Community Medicine. 2014 Apr;301(1922):1-3.

17. Tzioumis E, Adair LS. Childhood dual burden of under-and overnutrition in low-and middleincome countries: a critical review. Food and nutrition bulletin. 2014 Jun;35 (2):230-43.

18. Moraeus L, Lissner L, Yngve A, et al. A. Multi-level influences on childhood obesity in Sweden: societal factors, parental 
determinants and child's lifestyle.

International Journal of Obesity. 2012 Jul; 36(7):969.

19. Freedman MR, Keast DR. White potatoes, including French fries, contribute shortfall nutrients to children's and adolescents' diets. Nutrition research. 2011 Apr 1;31(4):270-7.

20. Olsho LE, Fernandes MM. Relationship of white potato to other vegetable consumption by schoolchildren and adolescents in the USA: National Health and Nutrition Examination Survey,
2003-2008. Public health nutrition. 2013 Nov;16(11):1933-6.

21. Wolde T, Belachew T, Birhanu T. Prevalence of undernutrition and determinant factors among preschool children in Hawassa, Southern Ethiopia. Prevalence. 2014; 29:16-24.

22. Rodgers RF, Paxton SJ, Massey R, et al. Maternal feeding practices predict weight gain and obesogenic eating behaviors in young children: a prospective study. International Journal of Behavioral Nutrition and Physical Activity. 2013 Dec;10 (1):24. 


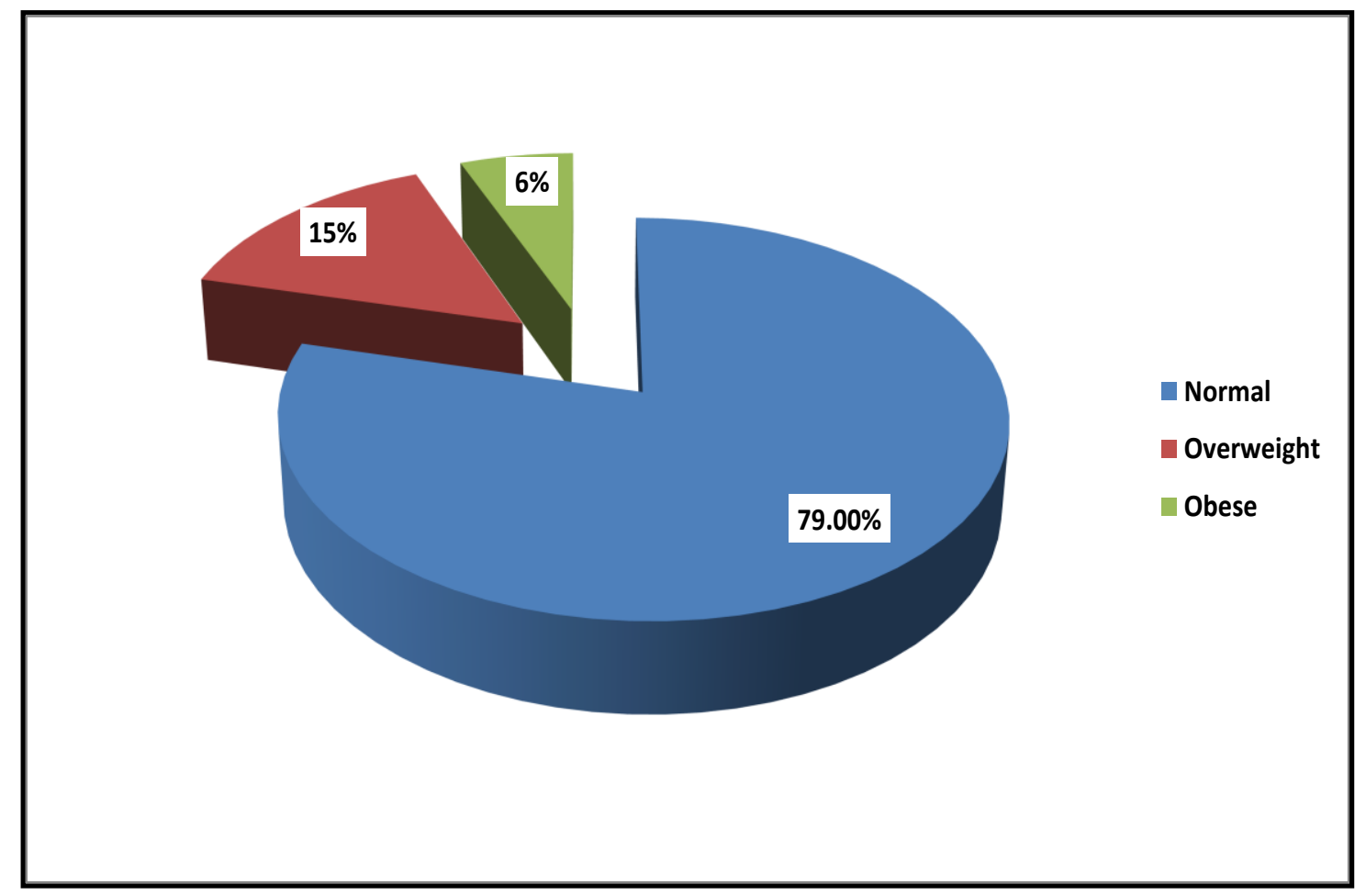

Fig (1): Prevalence of overweight and obesity of the studied group.

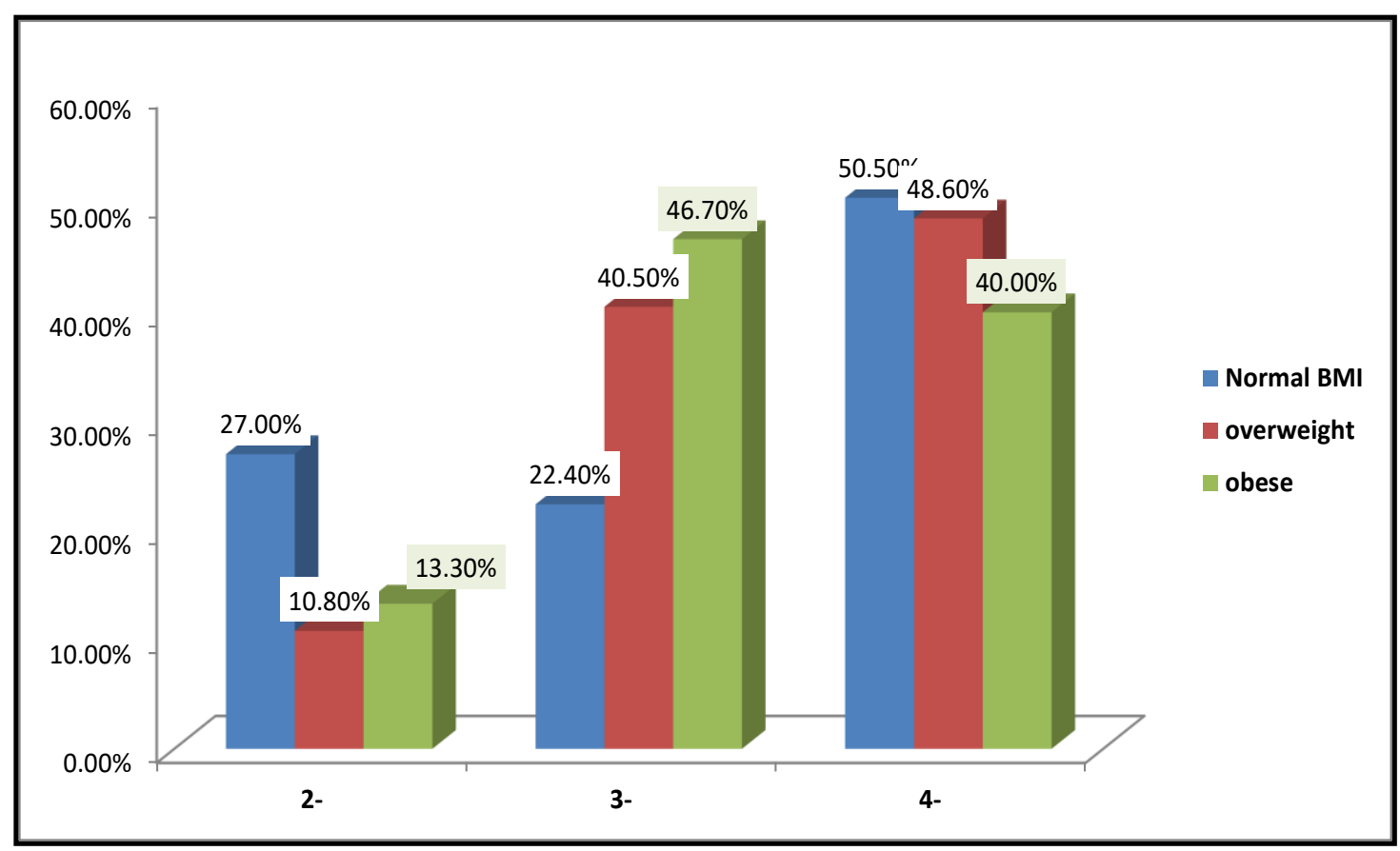

Fig (2): Frequency of overweight and obesity among studied group according to age 
Table (1): Relationship between BMI of the studied group and sociodemographic characteristics

\begin{tabular}{|c|c|c|c|c|c|c|c|c|}
\hline \multirow[b]{2}{*}{ Parameter } & \multicolumn{2}{|c|}{ Normal BMI } & \multicolumn{2}{|c|}{ Overweight } & \multicolumn{2}{|c|}{ Obese } & \multirow{2}{*}{$\begin{array}{l}\text { Chi- } \\
\text { square }\end{array}$} & \multirow[b]{2}{*}{ p-value } \\
\hline & $\begin{array}{l}\text { No } \\
196\end{array}$ & $\begin{array}{c}\% \\
79.0\end{array}$ & $\begin{array}{l}\text { No } \\
37\end{array}$ & $\begin{array}{c}\% \\
17.9\end{array}$ & $\begin{array}{l}\text { No } \\
15\end{array}$ & $\begin{array}{c}\% \\
6.0\end{array}$ & & \\
\hline $\begin{aligned} & \text { Age } \\
& . 2- \\
& \cdot 3- \\
& \cdot 4-5 y e a r s \\
&\end{aligned}$ & $\begin{array}{l}53 \\
44 \\
99\end{array}$ & $\begin{array}{l}27.0 \\
22.4 \\
50.5\end{array}$ & $\begin{array}{c}4 \\
15 \\
18\end{array}$ & $\begin{array}{l}10.8 \\
40.5 \\
48.6\end{array}$ & $\begin{array}{l}2 \\
7 \\
6 \\
\end{array}$ & $\begin{array}{l}13.3 \\
46.7 \\
40.0 \\
\end{array}$ & 10.73 & $0.03 *$ \\
\hline $\begin{aligned} \text { Gender } \\
\text { - } \\
\text { - } \text { Male } \\
\end{aligned}$ & $\begin{array}{c}107 \\
89\end{array}$ & $\begin{array}{l}54.6 \\
45.4 \\
\end{array}$ & $\begin{array}{l}10 \\
27 \\
\end{array}$ & $\begin{array}{l}27.0 \\
73.0\end{array}$ & $\begin{array}{c}12 \\
3 \\
\end{array}$ & $\begin{array}{l}80.0 \\
20.0\end{array}$ & 14.48 & $0.001 *$ \\
\hline $\begin{array}{cl}\text { Family history of obesity } \\
-\quad \text { Yes } \\
-\quad \text { No }\end{array}$ & $\begin{array}{c}95 \\
101\end{array}$ & $\begin{array}{l}48.5 \\
51.5\end{array}$ & $\begin{array}{l}15 \\
22\end{array}$ & $\begin{array}{l}40.5 \\
59.5\end{array}$ & $\begin{array}{l}6 \\
9\end{array}$ & $\begin{array}{l}40.0 \\
60.0\end{array}$ & 1.08 & 0.583 \\
\hline $\begin{array}{c}\text { Work of the mother } \\
\text { - Housewife } \\
\text { - Working }\end{array}$ & $\begin{array}{c}121 \\
75\end{array}$ & $\begin{array}{l}61.7 \\
38.3\end{array}$ & $\begin{array}{l}22 \\
15\end{array}$ & $\begin{array}{l}59.5 \\
40.5\end{array}$ & $\begin{array}{c}12 \\
3\end{array}$ & $\begin{array}{l}80.0 \\
20.0\end{array}$ & 2.15 & 0.340 \\
\hline $\begin{array}{c}\text { Mother education } \\
\text { - Primary to middle } \\
\text { - } \text { High school } \\
\text { - University } \\
\end{array}$ & $\begin{array}{c}47 \\
24 \\
125 \\
\end{array}$ & $\begin{array}{l}24.0 \\
12.2 \\
63.8 \\
\end{array}$ & $\begin{array}{c}17 \\
0 \\
20 \\
\end{array}$ & $\begin{array}{c}45.9 \\
0.0 \\
54.1 \\
\end{array}$ & $\begin{array}{c}0 \\
2 \\
13 \\
\end{array}$ & $\begin{array}{c}0.0 \\
13.3 \\
86.7\end{array}$ & 16.29 & $0.003 *$ \\
\hline $\begin{array}{l}\text { Socioeconomic level } \\
\text { - Low } \\
\text { - Middle } \\
\text { - High }\end{array}$ & $\begin{array}{c}58 \\
110 \\
28\end{array}$ & $\begin{array}{l}29.6 \\
56.1 \\
14.3\end{array}$ & $\begin{array}{c}19 \\
13 \\
5\end{array}$ & $\begin{array}{l}51.4 \\
35.1 \\
13.5\end{array}$ & $\begin{array}{l}6 \\
9 \\
0\end{array}$ & $\begin{array}{c}40.0 \\
60.0 \\
0.0\end{array}$ & 9.45 & 0.051 \\
\hline
\end{tabular}

BMI: Body mass index

*statistically significant $(\mathrm{p}<0.05)$ 
Table (2): Relationship between BMI of the studied children and frequency of eating different kinds of food

\begin{tabular}{|c|c|c|c|c|c|c|c|c|}
\hline \multirow[b]{2}{*}{ Parameter } & \multicolumn{2}{|c|}{ Normal BMI } & \multicolumn{2}{|c|}{ Overweight } & \multicolumn{2}{|c|}{ Obese } & \multirow[b]{2}{*}{$\begin{array}{l}\text { Chi- } \\
\text { square }\end{array}$} & \multirow[b]{2}{*}{$\begin{array}{c}\text { p- } \\
\text { value }\end{array}$} \\
\hline & $\begin{array}{c}\text { No } \\
196\end{array}$ & $\begin{array}{c}\% \\
79.0\end{array}$ & $\begin{array}{l}\text { No } \\
37\end{array}$ & $\begin{array}{c}\% \\
17.9\end{array}$ & $\begin{array}{l}\text { No } \\
15\end{array}$ & $\begin{array}{l}\% \\
6.0\end{array}$ & & \\
\hline $\begin{array}{l}\text { Frequency of eating } \\
\text { junk food } \\
\text { - } \text { Never } \\
\text { - } \text { Every day } \\
\text { - } 1-2 \text { times/ week } \\
\text { - } \geq 3 \text { times /week }\end{array}$ & $\begin{array}{c}141 \\
51 \\
3 \\
1\end{array}$ & $\begin{array}{c}71.9 \\
26.0 \\
1.5 \\
0.5\end{array}$ & $\begin{array}{c}9 \\
28 \\
0 \\
0\end{array}$ & $\begin{array}{c}24.3 \\
75.7 \\
0.0 \\
0.0\end{array}$ & $\begin{array}{l}8 \\
7 \\
0 \\
0\end{array}$ & $\begin{array}{c}53.3 \\
46.7 \\
0.0 \\
0.0\end{array}$ & 35.199 & $* 0.001$ \\
\hline $\begin{aligned} & \text { Frequency of eating } \\
& \text { fried food } \\
& \text { : } \text { Never } \\
& \text { : } \text { Every day } \\
& \text { - } \geq 3 \text { times/ week } / \text { week }\end{aligned}$ & $\begin{array}{c}31 \\
50 \\
103 \\
12\end{array}$ & $\begin{array}{c}15.8 \\
25.5 \\
52.6 \\
6.1\end{array}$ & $\begin{array}{c}2 \\
10 \\
25 \\
0\end{array}$ & $\begin{array}{c}5.4 \\
27.0 \\
67.6 \\
0.0\end{array}$ & $\begin{array}{l}2 \\
9 \\
4 \\
0\end{array}$ & $\begin{array}{c}13.3 \\
60.0 \\
26.7 \\
0.0\end{array}$ & 14.983 & 0.02 \\
\hline $\begin{array}{l}\text { Frequency of drinking } \\
\text { milk } \\
\text { - } \\
\text { - } \text { Evever } \\
\text { - } 1-2 \text { times/ week } \\
\text { - } \geq 3 \text { times / week }\end{array}$ & $\begin{array}{c}51 \\
105 \\
37 \\
3\end{array}$ & $\begin{array}{c}26.0 \\
53.6 \\
18.9 \\
1.5\end{array}$ & $\begin{array}{c}12 \\
21 \\
2 \\
2\end{array}$ & $\begin{array}{c}32.4 \\
56.8 \\
5.4 \\
5.4\end{array}$ & $\begin{array}{c}0 \\
14 \\
1 \\
0\end{array}$ & $\begin{array}{c}0.0 \\
93.3 \\
6.7 \\
0.0\end{array}$ & 15.491 & 0.017 \\
\hline $\begin{array}{l}\text { Frequency of eating } \\
\text { milk product } \\
\text { - Never } \\
\text { - } \quad \text { Every day } \\
\text { - } 1-2 \text { times/ week } \\
\text { - }>3 \text { times /week }\end{array}$ & $\begin{array}{l}39 \\
70 \\
83 \\
4\end{array}$ & $\begin{array}{l}19.9 \\
35.7 \\
42.3 \\
2.0\end{array}$ & $\begin{array}{l}2 \\
26 \\
7 \\
2\end{array}$ & $\begin{array}{l}5.4 \\
70.3 \\
18.9 \\
5.4\end{array}$ & $\begin{array}{l}0 \\
12 \\
3 \\
0\end{array}$ & $\begin{array}{l}0.0 \\
80.0 \\
20.0 \\
0.0\end{array}$ & 27.702 & $0.001 *$ \\
\hline $\begin{array}{l}\text { Frequency of eating } \\
\text { animal protein } \\
\text {. Never } \\
\text { - Every day } \\
\text { - } 1-2 \text { times/ week } \\
\text { - }>3 \text { times/week }\end{array}$ & $\begin{array}{c}17 \\
147 \\
26 \\
5\end{array}$ & $\begin{array}{c}8.7 \\
75.4 \\
13.3 \\
2.6\end{array}$ & $\begin{array}{c}2 \\
33 \\
2 \\
0\end{array}$ & $\begin{array}{c}5.4 \\
89.2 \\
5.4 \\
0.0\end{array}$ & $\begin{array}{c}1 \\
14 \\
0 \\
0\end{array}$ & $\begin{array}{c}6.7 \\
93.3 \\
0.0 \\
0.0\end{array}$ & 6.529 & 0.367 \\
\hline $\begin{array}{l}\text { Frequency of eating } \\
\text { vegetable } \\
\text { - Never } \\
\text { - Every day } \\
\text { - } 1-2 \text { times/week } \\
\text { - }>3 \text { times/week }\end{array}$ & $\begin{array}{c}61 \\
84 \\
44 \\
6\end{array}$ & $\begin{array}{c}31.3 \\
43.1 \\
22.6 \\
3.1\end{array}$ & $\begin{array}{c}12 \\
14 \\
11 \\
0\end{array}$ & $\begin{array}{c}32.4 \\
37.8 \\
29.7 \\
0.0\end{array}$ & $\begin{array}{c}3 \\
2 \\
10 \\
0\end{array}$ & $\begin{array}{c}20.0 \\
13.3 \\
66.7 \\
0.0\end{array}$ & 5.680 & 0.460 \\
\hline $\begin{array}{l}\text { Frequency of eating } \\
\text { fruits } \\
\text { : } \\
\text { - } \text { Evevery day } \\
\text { - } 1-2 \text { times/ week } \\
\quad \geq 3 \text { times/week }\end{array}$ & $\begin{array}{c}16 \\
137 \\
37 \\
6\end{array}$ & $\begin{array}{c}8.2 \\
69.9 \\
18.9 \\
3.1\end{array}$ & $\begin{array}{c}0 \\
11 \\
26 \\
0\end{array}$ & $\begin{array}{c}0.0 \\
29.7 \\
70.3 \\
0.0\end{array}$ & $\begin{array}{c}0 \\
2 \\
13 \\
0\end{array}$ & $\begin{array}{c}0.0 \\
13.3 \\
86.7 \\
0.0\end{array}$ & 8.586 & 0.198 \\
\hline
\end{tabular}

*Statistically significant $(\mathrm{p}<0.05)$ 
Table (3): Relationship between BMI of the studied children and their dietary habits and life style

\begin{tabular}{|c|c|c|c|c|c|c|c|c|}
\hline \multirow{2}{*}{ Parameter } & \multicolumn{2}{|c|}{$\begin{array}{c}\text { Normal BMI } \\
(196)\end{array}$} & \multicolumn{2}{|c|}{$\begin{array}{c}\text { Overweight } \\
(37)\end{array}$} & \multicolumn{2}{|c|}{$\begin{array}{c}\text { Obese } \\
(15)\end{array}$} & \multirow[b]{2}{*}{$\begin{array}{l}\text { Chi- } \\
\text { square }\end{array}$} & \multirow{2}{*}{$\begin{array}{c}\mathbf{P} \\
\text { value }\end{array}$} \\
\hline & No & $\%$ & No & $\%$ & No & $\%$ & & \\
\hline $\begin{array}{c}\text { Main meal per day } \\
\text { - } \text { Breakfast } \\
\text { - Lunch } \\
\text { - } \text { Dinner } \\
\end{array}$ & $\begin{array}{c}14 \\
140 \\
42 \\
\end{array}$ & $\begin{array}{c}7.1 \\
71.4 \\
21.4 \\
\end{array}$ & $\begin{array}{c}2 \\
15 \\
20\end{array}$ & $\begin{array}{c}5.4 \\
40.5 \\
54.1 \\
\end{array}$ & $\begin{array}{l}0 \\
8 \\
7\end{array}$ & $\begin{array}{c}0.0 \\
53.3 \\
46.7 \\
\end{array}$ & 20.01 & $0.001 *$ \\
\hline $\begin{array}{l}\text { No. of snacks per } \\
\text { day } \\
\begin{array}{ll}\text { - } & 1 \\
\text { - } & 2 \\
\text { - } & \geq 3\end{array}\end{array}$ & $\begin{array}{c}34 \\
123 \\
39\end{array}$ & $\begin{array}{l}17.3 \\
62.8 \\
19.9\end{array}$ & $\begin{array}{c}5 \\
28 \\
4\end{array}$ & $\begin{array}{l}13.5 \\
75.7 \\
10.8\end{array}$ & $\begin{array}{l}6 \\
6 \\
3\end{array}$ & $\begin{array}{l}40.0 \\
40.0 \\
20.0\end{array}$ & 8.04 & 0.089 \\
\hline $\begin{array}{cl}\text { Kind of snacks } \\
\text { - } & \text { Sweet } \\
\text { - } & \text { Salty } \\
\text { - } & \text { Both }\end{array}$ & $\begin{array}{c}44 \\
43 \\
109\end{array}$ & $\begin{array}{l}22.4 \\
21.9 \\
55.6\end{array}$ & $\begin{array}{c}15 \\
3 \\
19\end{array}$ & $\begin{array}{c}40.5 \\
8.1 \\
51.4\end{array}$ & $\begin{array}{l}6 \\
2 \\
7\end{array}$ & $\begin{array}{l}40.0 \\
13.3 \\
46.7\end{array}$ & 8.70 & 0.069 \\
\hline $\begin{array}{c}\text { Outdoor activity } \\
\text { - No } \\
\text { - Yes }\end{array}$ & $\begin{array}{l}126 \\
70\end{array}$ & $\begin{array}{l}64.3 \\
35.7\end{array}$ & $\begin{array}{l}21 \\
16\end{array}$ & $\begin{array}{l}56.8 \\
43.2\end{array}$ & $\begin{array}{c}14 \\
1\end{array}$ & $\begin{array}{c}93.3 \\
6.7\end{array}$ & 12.24 & $0.002 *$ \\
\hline $\begin{array}{c}\text { Sport activity } \\
\text { - } \mathrm{No} \\
\text { - } \mathrm{Yes}\end{array}$ & $\begin{array}{l}160 \\
36\end{array}$ & $\begin{array}{l}81.6 \\
18.4\end{array}$ & $\begin{array}{l}26 \\
11\end{array}$ & $\begin{array}{l}70.3 \\
29.7\end{array}$ & $\begin{array}{l}15 \\
0\end{array}$ & $\begin{array}{c}100.0 \\
0.0\end{array}$ & 6.34 & $0.042 *$ \\
\hline
\end{tabular}

*Statistically significant $(\mathrm{p}<0.05)$ 
Table (4): Relationship between BMI of the studied group and maternal feeding behavior

\begin{tabular}{|c|c|c|c|c|c|c|c|c|}
\hline \multirow[t]{2}{*}{ Parameter } & \multicolumn{2}{|c|}{$\begin{array}{c}\text { Normal } \\
\text { BMI } \\
(\mathbf{1 9 6 )} \\
\end{array}$} & \multicolumn{2}{|c|}{$\begin{array}{c}\text { Overweight } \\
\text { (37) }\end{array}$} & \multicolumn{2}{|c|}{$\begin{array}{c}\text { Obese } \\
\text { (15) }\end{array}$} & \multirow{2}{*}{$\begin{array}{l}\text { Chi- } \\
\text { square }\end{array}$} & \multirow[t]{2}{*}{ p-value } \\
\hline & No & $\%$ & No & $\%$ & No & $\%$ & & \\
\hline $\begin{array}{l}\text { Allowing child to eat } \\
\text { alone } \\
\text { - No } \\
\text { - Yes }\end{array}$ & $\begin{array}{c}79 \\
117 \\
\end{array}$ & $\begin{array}{l}40.3 \\
59.7\end{array}$ & $\begin{array}{c}7 \\
30 \\
\end{array}$ & $\begin{array}{l}18.9 \\
81.1\end{array}$ & $\begin{array}{c}1 \\
14\end{array}$ & $\begin{array}{c}6.7 \\
93.3\end{array}$ & 11.911 & $0.003^{*}$ \\
\hline $\begin{array}{l}\text { Regular sweet } \\
\text { intake } \\
\text { - No } \\
\text { - Yes }\end{array}$ & $\begin{array}{c}40 \\
156\end{array}$ & $\begin{array}{l}20.4 \\
79.6\end{array}$ & $\begin{array}{c}5 \\
32\end{array}$ & $\begin{array}{l}13.5 \\
86.5\end{array}$ & $\begin{array}{c}12 \\
3\end{array}$ & $\begin{array}{l}20.0 \\
80.0\end{array}$ & 30.157 & $0.001 *$ \\
\hline $\begin{array}{l}\text { Offering sweet as a } \\
\text { reward } \\
\text { - No } \\
\text { - Yes }\end{array}$ & $\begin{array}{c}34 \\
162\end{array}$ & $\begin{array}{l}17.3 \\
82.7\end{array}$ & $\begin{array}{c}1 \\
36\end{array}$ & $\begin{array}{c}2.7 \\
97.3\end{array}$ & $\begin{array}{c}2 \\
13\end{array}$ & $\begin{array}{l}13.3 \\
86.7\end{array}$ & 5.290 & 0.071 \\
\hline $\begin{array}{l}\text { Forcing child to eat } \\
\text { without being } \\
\text { hungry } \\
\text { - } \mathrm{No} \\
\text { - Yes }\end{array}$ & $\begin{array}{c}126 \\
70\end{array}$ & $\begin{array}{l}64.3 \\
35.7\end{array}$ & $\begin{array}{l}25 \\
12\end{array}$ & $\begin{array}{l}67.6 \\
32.4\end{array}$ & $\begin{array}{c}11 \\
4\end{array}$ & $\begin{array}{l}73.3 \\
26.7\end{array}$ & 0.600 & 0.741 \\
\hline $\begin{array}{l}\text { Maternal Concern } \\
\text { about overweight } \\
\text { - No } \\
\text { - Yes } \\
\end{array}$ & $\begin{array}{c}127 \\
69 \\
\end{array}$ & $\begin{array}{l}64.8 \\
35.2 \\
\end{array}$ & $\begin{array}{c}7 \\
30 \\
\end{array}$ & $\begin{array}{l}18.9 \\
81.1 \\
\end{array}$ & $\begin{array}{c}1 \\
14 \\
\end{array}$ & $\begin{array}{c}6.7 \\
93.3 \\
\end{array}$ & 41.099 & $0.001 *$ \\
\hline $\begin{array}{l}\text { Keeping food out of } \\
\text { reach } \\
\text { - No } \\
\text { - } \text { Yes } \\
\end{array}$ & $\begin{array}{c}110 \\
86 \\
\end{array}$ & $\begin{array}{l}56.1 \\
43.9 \\
\end{array}$ & $\begin{array}{c}31 \\
6 \\
\end{array}$ & $\begin{array}{l}83.8 \\
16.2 \\
\end{array}$ & $\begin{array}{c}10 \\
5 \\
\end{array}$ & $\begin{array}{l}66.7 \\
33.3\end{array}$ & 10.224 & $0.006^{*}$ \\
\hline
\end{tabular}

*Statistically significant $(\mathrm{p}<0.05)$ 


\section{الملخص العربي}

زيادة الوزن والسمنة بين الأطفال قبل سن المدرسة المترددين على وحدة ريفية لطب الاسرة ـ محافظة

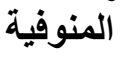
نورا عبد الهادى خليلــ داليا مصطفى اللاهونى ـ ألاء عادل مجاهد

الخلفية: السمنة عند الأطفال في سن ما قبل المدرسة هي مشكلة متنامية لأنها تتبئ بسمنة البلوغ والاعتلال و الوفيات.الهـف: تقييم مدى انتشار السمنة وتحديد عو امل الخطر بين الأطفال ما قبل المدرسة. المنهجية و طرق البحث: أجريت دراسة مقطعية على 248 طفل ما قبل المدرسة من الجنسين ، تتز اوح أعمار هم بين 2-2 سنوات في المناطق الريفية في محافظة المنوفية. نم جمع البيانات الاجتماعية والديموغر افية للأطفال الذين شملتهم الدر اسة وممارساتهم الغذائية من أمهات الأطفال الذين شملتهم الدر اسة. تم قياس الوزن و والطول ونم حساب مؤشر كتلة الجسم مع استخدام إرشادات الممارسة المصرية للقيم الفاصلة لمؤشر كتلة الجسم مقابل

$$
\text { العمرو استخدمت النسب المئوية لتحديد مدى انتشار فرط الوزن و السمنة. }
$$

النتائج: إجمالي انتشار زيادة الوزن و السمنة مجتمعة 21 ٪( 15 ٪ لزيادة الوزن و 6 \% للسمنة). معدل الانتشار أعلى بين الذين تتر اوح أعمار هم بين 3-4 سنوات (46.7 \%) وكان 80 \% منهم من الذكور ـ ارتبط تثقيف الأمهات و الوجبات السريعة والأطعمة المقلية بشكل كبير بزيادة الوزن والسمنة . أيضًا تأثر مؤشر كتلة الجسم بشكل كبير بسلوك التخذية الأمو مية (مثل السماح للطفل بالأكل بمفرده وتقديم الحلويات بانتظام وتقديم الحلويات كك مكافأة ، قلق

$$
\text { الأم حول زيادة الوزن و الحفاظ على الطعام بعيد المنال). }
$$

الاستتتاج: يزداد معدل انتشار السمنة قبل سن المدرسة مع عوامل الخطر المتعددة ، مثل نعليم الأم ، وتواتر

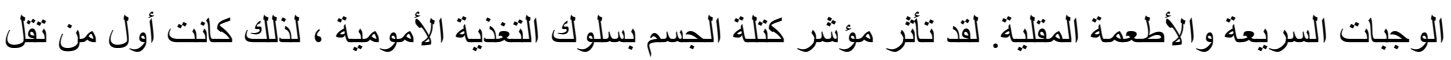
عن خمس سنوات من العمر أفضل فترة للتنخل فيما يتعلق بالوقاية من السمنة الأولية. الكلمات المفتاحية: الانتشار ، عوامل الخطر ، عادات الأكل. 